\title{
Effect of DHA supplementation on digestible starch utilization by rainbow trout
}

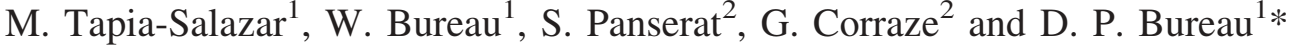 \\ ${ }^{1}$ Department of Animal and Poultry Science, University of Guelph, Guelph, ON, N1G2W1, Canada \\ ${ }^{2}$ UMR Nutrition Aquaculture Génomique, INRA, 64310 St-Pée-sur-Nivelle, France
}

(Received 12 January 2005 - Revised 5 August 2005 - Accepted 22 August 2005)

\begin{abstract}
Rainbow trout has a limited ability to utilize digestible carbohydrates efficiently. Trout feeds generally contain high levels of DHA, a fatty acid known to inhibit a number of glycolytic and lipogenic enzymes in animals. A study was conducted to determine whether carbohydrate utilization by rainbow trout might be affected by dietary DHA level. Two low-carbohydrate ( $<4 \%$ digestible carbohydrate) basal diets were formulated to contain 1 (adequate) or 4 (excess) g/100 g DHA diet respectively. The two basal diets were diluted with increasing levels of digestible starch (0\%, $10 \%, 20 \%$ and $30 \%$, respectively) to produce eight diets. These diets were fed to fish for 12 weeks at $15^{\circ} \mathrm{C}$ according to a pair-fed protocol that consisted of feeding the same amount of basal diet but different amounts of starch. Live weight, $\mathrm{N}$ and lipid gains, hepatic glycogen and plasma glucose values significantly increased, whereas feed efficiency (gain:feed) significantly decreased, with increasing starch intake $(P<0 \cdot 05)$. The retention efficiency of $\mathrm{N}$ ( $\mathrm{N}$ gain/digestible $\mathrm{N}$ intake) improved with starch supplementation but was not affected by DHA level $(P>0 \cdot 05)$. Starch increased the activity of glucokinase, pyruvate kinase, glucose 6-phosphate dehydrogenase and fatty acid synthase $(P<0.05)$ but did not affect hexokinase and malic enzyme activity. DHA had no effect on growth but increased plasma glucose and reduced carcass lipid and liver glycogen contents $(P<0 \cdot 05)$. Glycolytic and lipogenic enzymes were not affected by DHA level, except for pyruvate kinase, which was reduced by increasing DHA level. These results suggest only a marginal effect of dietary DHA on the ability of fish to utilize carbohydrate.
\end{abstract}

Rainbow trout: Dietary carbohydrates: PUFA: DHA: Glycolytic and lipogenic enzymes

The nutritive value and fate of digestible carbohydrate in fish is a relatively controversial issue. Studies suggest that digestible glucose (e.g. from dietary starch, dextrins or glucose) is used as efficiently as amino acids and fatty acids by rainbow trout to support protein or lipid deposition (Bergot, 1979; Pieper \& Pfeffer, 1980; Kaushik \& Oliva-Teles, 1985; Kim \& Kaushik, 1992; Brauge et al. 1994; Capilla et al. 2003). In contrast, other studies have suggested that digestible carbohydrates are not very effective net energy sources as, at high dietary intakes, digestible glucose has very limited effects on protein and lipid deposition in salmonid fish species (Hilton \& Atkinson, 1982; March et al. 1985; Beamish et al. 1986; Hilton et al. 1987; Bureau et al. 1998; Helland \& Grisdale-Helland, 1998). This has been tentatively explained by the difference in the protein and lipid contents of the diet used and a poor capability to synthesize lipid from the absorbed glucose (Brauge et al. 1995; Bureau et al. 1998; Hemre \& Storebakken, 2000; Hemre et al. 2002). Reconciliation of the results from diverging studies is difficult because of the numerous variables involved (e.g. differences in dietary protein, amino acids, lipid and carbohydrate levels, feeding protocol, etc.). Adequately studying the utilization of carbohydrate requires the use of a protocol in which only digestible carbohydrate intake varies.
In mammals, dietary carbohydrates enhance the activity of the enzymes involved in the metabolism of lipids and carbohydrates (Iritani, 1992; Towle et al. 1997). Studies with marine and freshwater fish have also shown that dietary carbohydrates increased the activity of glycolytic and lipogenic enzymes (Lin et al. 1977a; Tranulis et al. 1996; Dias et al. 1998; Panserat et al. 2000a,b, 2001a,b; Barroso et al. 2001; Capilla et al. 2003; Rollin et al. 2003).

The activity of some glycolytic and lipogenic enzymes has also been shown to be affected by the lipid and PUFA contents of the diet in both mammalian and teleost species (Lin et al. 1977b; Jürss et al. 1985; Clarke \& Abraham, 1992; Clarke \& Jump, 1992; Fynn-Aikins et al. 1992; Iritani, 1992; Arnesen et al. 1993; Clarke, 1993; Shimeno et al. 1996; Dias et al. 1998; Clarke, 2000; Gélineau et al. 2001; Rollin et al. 2003). In vitro and in vivo studies with mammals have shown that $n$-3 PUFA, notably EPA and DHA, have potent abilities to alter the metabolism of lipid and carbohydrates (Rustan et al. 1993; Jump et al. 1994; Mashek \& Grummer, 2003). Fatty acids are important mediators of gene expression in the liver. Genes encoding both glycolytic and lipogenic enzymes and key metabolic enzymes involved in fatty-acid oxidation are regulated by dietary PUFA (Raclot \& Oudart, 1999).

Abbreviations: AD, adequate DHA; CP, crude protein; ED, excess DHA; FAS, fatty acid synthase; G6PDH, glucose 6-phosphate dehydrogenase; GE, gross energy; HK, hexokinase; ME, malic enzyme; PK, pyruvate kinase.

* Corresponding author: Dr Dominique P. Bureau, fax +1 519767 0573, email dbureau@uoguelph.ca 
Fish feeds generally contain high levels of the $n$-3 PUFA DHA, a fatty acid known to reduce mRNA encoding for some enzymes involved in the metabolism of lipid and carbohydrates (Jump et al. 1994), alter plasma glucose (Rustan et al. 1993) and reduce glycogen deposition (Rustan et al. 1993; Mashek \& Grummer, 2003). An inhibitory effect of DHA on the activity of lipogenic enzymes has been observed in fish hepatocytes (Alvarez et al. 2000). These observations suggest that the ability of fish to efficiently utilize dietary carbohydrate may be affected by the $n-3$ PUFA or DHA content of the diet.

The aim of this study was to determine the effect of dietary DHA level on growth performance, nutrient deposition and the activity of glycolytic and lipogenic enzymes in rainbow trout fed increasing levels of digestible starch.

\section{Material and methods}

Diets

Two low-carbohydrate basal diets (Table 1) were formulated to contain $1 \%$ DHA (adequate, AD) and $4 \%$ DHA (excess, ED). The basal diets were diluted with gelatinized starch (S) in different proportions to produce eight diets: AD:0S, ED:0S, AD:10S, ED:10S, AD:20S, ED:20S, AD:30S, ED:30S (Tables 2 and 3). Acid-washed diatomaceous silica (Celite AW521, Celite, Lompoc, CA, USA) was included in the diet as a digestibility indicator. The diets were mixed using a Hobart mixer (Hobart, Don Mills, Ontario, Canada) and pelleted to the appropriate size using a laboratory steam pellet mill (California Pellet Mill, San Francisco, CA, USA). The feed pellets were dried under forced air at room temperature for $24 \mathrm{~h}$ and then sieved. The diets were kept at $-4^{\circ} \mathrm{C}$ until used, and only the amount required for each week was kept at room temperature.

Table 1. Composition of the basal diets $(\mathrm{g} / \mathrm{kg})$

\begin{tabular}{lcc}
\hline & Adequate DHA & Excess DHA \\
\hline Fish meal & 550 & 550 \\
Blood meal, whole, spray-dried & 150 & 150 \\
Casein & 140 & 140 \\
Celite AW521† & 10 & 10 \\
Lignosolł & 20 & 20 \\
Vitamin premix§ & 20 & 20 \\
Mineral premix\| & 10 & 10 \\
Olive oil & 100 & 50 \\
Fish-oil concentrate & - & 50 \\
\hline
\end{tabular}

†Celite AW521 (acid-washed diatomaceous silica) is a source of acid-insoluble ash.

‡Lingosulfonate, from Martin Mills, Tavistock, Ontario, Canada.

§ Provides per kg diet: $3750 \mathrm{IU}$ retinyl acetate, $3600 \mathrm{IU}$ cholecalciferol, $75 \mathrm{IU} 2 \mathrm{DL}-\mathrm{a}$ tocopherol-acetate, $1.5 \mathrm{mg}$ menadione sodium bisulphate, $0.03 \mathrm{mg}$ cyanocobalamin, $75 \mathrm{mg}$ ascorbic acid monophosphate, $0.225 \mathrm{mg}$ D-biotin, $1500 \mathrm{mg}$ choline chloride, $1.5 \mathrm{mg}$ folic acid, $4500 \mathrm{mg}$ myoinositol, $15 \mathrm{mg}$ niacin, $30 \mathrm{mg}$ calcium Dpantothenate, $7.5 \mathrm{mg}$ pyridoxine hydrochloride, $6 \mathrm{mg}$ riboflavin, $1.5 \mathrm{mg}$ thiamin hydrochloride.

|| Provides per kg diet: $1200 \mathrm{mg} \mathrm{NaCl}(39 \% \mathrm{Na}, 61 \% \mathrm{Cl}), 13 \mathrm{mg} \mathrm{FeSO}, 32 \mathrm{mg}$ $\mathrm{MnSO}_{4}, 60 \mathrm{mg} \mathrm{ZnSO}_{4}, 7 \mathrm{mg} \mathrm{CuSO}_{4}, 8 \mathrm{mg} \mathrm{KI}$.

ๆ 03/55 TG fish-oil concentrate from Ocean-Nutrition, Halifax, Nova Scotia, Canada. Fatty-acid profile: EPA $90 \mathrm{mg} / \mathrm{g}$, DHA $380 \mathrm{mg} / \mathrm{g}$ expressed as free fatty acids.

\section{Fish and experimental conditions}

Juvenile rainbow trout, Oncorhynchus mykiss, were obtained from a broodstock held at the Alma Aquaculture Research Station (Elora, Ontario, Canada). Ten fish (initial body weight $79 \pm 2 \mathrm{~g}$ mean $\pm \mathrm{SD}$ ) were randomly distributed into rectangular fibreglass tanks (60 litre) each, with three tank replicates per diet. The fish were hand-fed (three times a day) for 12 weeks according to a pair-fed protocol of Bureau et al. (1998), which consisted of feeding the same amount of basal diet, but different amount of digestible starch, to all the fish. In this experiment, fish fed diets $\mathrm{AD}: 30 \mathrm{~S}$ and ED:30S were fed near to satiation, and the feed allocation for the rest of the fish was adjusted so that they were allocated the same amount of basal diet.

Diets with low (AD:0S, ED:0S) and high (AD:30S and ED:30S) digestible starch levels were used in a second feeding trial (trial 2) to evaluate the effect of DHA supplementation on plasma glucose and liver composition. Eight fish (initial body weight $170 \pm 3 \mathrm{~g}$ ) were held per tank and fed for 12 weeks using the same feeding protocol described above. Each diet was fed to three tanks, and each tank was considered an experimental unit.

The tanks were supplied with filtered well water at $1.51 / \mathrm{min}$. Water temperature was maintained to $15^{\circ} \mathrm{C}$ by injecting hot water into the incoming water line. Each tank was individually aerated. Mortality and temperature were registered daily. Fish were weighed every $28 \mathrm{~d}$. The animals were held under artificial light, with a photoperiod regime of $12 \mathrm{~h}$ light $/ 12 \mathrm{~h}$ dark and treated in accordance with the guidelines of the Canadian Council on Animal Care (1984) and the University of Guelph Animal Care Committee.

\section{Fish sampling}

For initial carcass composition, a pooled sample of twenty-five fish was collected and stored at $-20^{\circ} \mathrm{C}$ until processed and analysed. At the end of the feeding trial, six fish per tank were taken and then weighed individually and gutted to determine the dressed carcass yield and hepatosomatic index. The pooled fish carcass samples (without liver) were cooked in an autoclave, ground into homogeneous slurry in a food processor, freeze-dried, finely ground and stored at $-20^{\circ} \mathrm{C}$ until analysis. Blood and liver sampling was scheduled to coincide with blood glucose and enzymatic activity peaks (Brauge et al. 1994; Gomez-Requeni et al. 2003; Mingarro \& Kirchner 2003). Blood (six samples per tank) and liver samples (three liver samples per tank) were taken from fish fed to satiation for $3 \mathrm{~d}$ and $6 \mathrm{~h}$ after the last morning meal and stored at $-80^{\circ} \mathrm{C}$ until analysed.

\section{Digestibility trial}

To evaluate the apparent digestibility of the nutrients in the experimental diets, faeces from diets AD:0S, ED:0S, $\mathrm{AD}: 30 \mathrm{~S}$ and ED:30S, representing the extreme of digestible carbohydrate content for each of the two diet DHA levels, were collected. Fifteen fish, weighing an average of $112 \pm$ $3 \mathrm{~g}$ mean $\pm \mathrm{SD}$, were stocked in an aquatic system equipped with faeces settling columns (Guelph system) described by Cho et al. (1982). The experimental diets were each randomly 
Table 2. Composition of the experimental diets $(\mathrm{g} / \mathrm{kg})$ supplemented with different levels of digestible starch and DHA

\begin{tabular}{|c|c|c|c|c|c|c|c|c|}
\hline & \multicolumn{4}{|c|}{ Diets with adequate DHA } & \multicolumn{4}{|c|}{ Diets with excess DHA } \\
\hline & AD:0S & AD:10S & AD:20S & $A D: 30 S$ & ED:OS & ED:10S & ED:20S & ED:30S \\
\hline \multicolumn{9}{|l|}{ Components } \\
\hline$A D$ & 1000 & 900 & 800 & 700 & - & - & - & - \\
\hline ED & - & - & - & - & 1000 & 900 & 800 & 700 \\
\hline Digestible starch & - & 100 & 200 & 300 & - & 100 & 200 & 300 \\
\hline \multicolumn{9}{|l|}{ Analysed composition (g/kg, DM basis) } \\
\hline DM & 937 & 941 & 939 & 936 & 952 & 952 & 952 & 951 \\
\hline Crude protein & 685 & 618 & 548 & 483 & 686 & 615 & 555 & 480 \\
\hline Crude lipid & 183 & 168 & 138 & 120 & 187 & 154 & 127 & 115 \\
\hline Total carbohydrate (calculated by difference) & 42 & 133 & 242 & 333 & 36 & 151 & 247 & 338 \\
\hline Ash & 90 & 81 & 72 & 64 & 91 & 80 & 71 & 67 \\
\hline Gross energy (kJ/g) & $24 \cdot 2$ & 23.4 & $22 \cdot 6$ & 21.9 & $24 \cdot 0$ & $23 \cdot 3$ & 22.5 & 21.8 \\
\hline
\end{tabular}

AD:0S, AD:10S, AD:20S, AD:30S, adequate DHA supplemented with 0\%, 10\%, 20\% and $30 \%$ digestible starch, respectively; ED:0S, ED:10S, ED:20S, ED:30S, excess DHA supplemented with $0 \%, 10 \%, 20 \%$ and $30 \%$ digestible starch, respectively. Nutrient content was evaluated per duplicate, and the CV between values was below $3 \%$.

allocated to four collection units. The fish were fed with the experimental diets for a 1-week acclimation period, and a total of four faeces samples per diet were collected over an 8 -week period. Two samples per diet were collected over the first 4-week period. The experimental diets were then randomly reallocated to new collection units for the second period, and two additional samples per diet were collected in the following 4-week period.

The fish were hand-fed to near satiation three times daily between 09.30 and $16.00 \mathrm{~h}$. Thirty minutes after the last daily meal, the drainpipe and the settling column were brushed out to remove feed residues and faeces from the system. At

Table 3. Fatty acid composition of the diets supplemented with different levels of digestible starch and DHA ( $/ 100 \mathrm{~g}$ diet)

\begin{tabular}{|c|c|c|c|c|c|c|c|c|}
\hline & \multicolumn{4}{|c|}{ Diets with adequate DHA } & \multicolumn{4}{|c|}{ Diets with excess DHA } \\
\hline & AD:0S & AD:10S & $A D: 20 S$ & $A D: 30 S$ & ED:OS & ED:10S & ED:20S & ED:30S \\
\hline C14: 0 & 0.37 & 0.34 & 0.27 & 0.24 & 0.42 & 0.36 & 0.29 & 0.27 \\
\hline C15: 0 & 0.03 & 0.03 & 0.00 & 0.02 & 0.03 & 0.03 & 0.02 & 0.02 \\
\hline C16: 0 & 2.54 & $2 \cdot 31$ & 1.90 & 1.64 & 2.05 & 1.73 & 1.40 & $1 \cdot 28$ \\
\hline C16: 1 & 0.39 & 0.35 & 0.29 & 0.25 & 0.42 & 0.35 & 0.29 & 0.26 \\
\hline C18: 0 & 0.49 & 0.45 & 0.37 & 0.32 & 0.39 & 0.34 & 0.27 & 0.25 \\
\hline C18: 1 & $8 \cdot 73$ & 8.03 & 6.56 & $5 \cdot 69$ & $5 \cdot 59$ & $4 \cdot 66$ & $3 \cdot 82$ & $3 \cdot 50$ \\
\hline C18:2n-6 & $1 \cdot 26$ & $1 \cdot 17$ & 0.97 & 0.82 & 0.85 & 0.69 & 0.59 & 0.51 \\
\hline C18: 3n-6 & 0.00 & 0.00 & 0.01 & 0.00 & 0.01 & 0.01 & 0.01 & 0.01 \\
\hline C18 : $3 n-3$ & 0.11 & 0.09 & 0.08 & 0.07 & 0.09 & 0.08 & 0.06 & 0.05 \\
\hline C18: $4 n-3$ & 0.06 & 0.06 & 0.05 & 0.04 & 0.08 & 0.07 & 0.06 & 0.05 \\
\hline C20 : 0 & 0.06 & 0.05 & 0.04 & 0.04 & 0.06 & 0.05 & 0.04 & 0.03 \\
\hline C20 : 1 & 0.74 & 0.68 & 0.55 & 0.48 & 0.97 & 0.77 & 0.65 & 0.58 \\
\hline C20 : 2n-6 & 0.01 & 0.00 & 0.01 & 0.00 & 0.00 & 0.02 & 0.01 & 0.01 \\
\hline $\mathrm{C} 20: 3 n-6$ & 0.00 & 0.00 & 0.01 & 0.00 & 0.02 & 0.01 & 0.01 & 0.01 \\
\hline C20 : 4n-6 & 0.03 & 0.03 & 0.03 & 0.02 & 0.07 & 0.06 & 0.05 & 0.05 \\
\hline $\mathrm{C} 20: 3 n-3$ & 0.00 & 0.01 & 0.00 & 0.00 & 0.00 & 0.03 & 0.01 & 0.01 \\
\hline C20 : $4 n-3$ & 0.02 & 0.02 & 0.02 & 0.01 & 0.07 & 0.06 & 0.04 & 0.04 \\
\hline $\mathrm{C} 20: 5 n-3$ & 0.40 & 0.37 & 0.30 & 0.27 & 1.03 & 0.88 & 0.69 & 0.64 \\
\hline C22 : 0 & 0.01 & 0.00 & 0.00 & 0.00 & 0.00 & 0.00 & 0.00 & 0.00 \\
\hline C22 : 1 & $1 \cdot 13$ & 1.07 & 0.86 & 0.77 & 1.63 & $1 \cdot 30$ & $1 \cdot 10$ & 0.95 \\
\hline C22 : 4n-6 & 0.00 & 0.00 & 0.00 & 0.00 & 0.03 & 0.03 & 0.02 & 0.02 \\
\hline C22 : $5 n-6$ & 0.00 & 0.01 & 0.00 & 0.01 & 0.09 & 0.07 & 0.05 & 0.05 \\
\hline C22 : $5 n-3$ & 0.06 & 0.06 & 0.04 & 0.05 & 0.51 & 0.42 & 0.34 & 0.32 \\
\hline C22 : $6 n-3$ & 0.66 & 0.63 & 0.50 & 0.46 & $3 \cdot 13$ & 2.57 & $2 \cdot 10$ & 1.90 \\
\hline $\mathrm{C} 24: 0$ & 0.02 & 0.03 & 0.02 & 0.01 & 0.02 & 0.01 & 0.01 & 0.02 \\
\hline C24 : 1 & 0.04 & 0.05 & 0.04 & 0.03 & 0.17 & 0.13 & 0.12 & $0 \cdot 10$ \\
\hline Total & $17 \cdot 17$ & $15 \cdot 83$ & 12.91 & $11 \cdot 24$ & $17 \cdot 76$ & $14 \cdot 70$ & $12 \cdot 06$ & $10 \cdot 93$ \\
\hline Saturated & 3.52 & $3 \cdot 20$ & $2 \cdot 60$ & $2 \cdot 26$ & 2.97 & $2 \cdot 51$ & $2 \cdot 04$ & $1 \cdot 87$ \\
\hline Monounsaturated & 11.03 & $10 \cdot 19$ & 8.29 & $7 \cdot 22$ & $8 \cdot 79$ & $7 \cdot 22$ & 5.97 & $5 \cdot 39$ \\
\hline$n-3$ & $1 \cdot 31$ & $1 \cdot 23$ & 0.99 & 0.90 & 4.92 & $4 \cdot 10$ & $3 \cdot 31$ & 3.01 \\
\hline$n-6$ & $1 \cdot 31$ & $1 \cdot 22$ & 1.02 & 0.86 & $1 \cdot 08$ & 0.87 & 0.74 & 0.66 \\
\hline$n-3 / n-6$ & 1.00 & 1.01 & 0.97 & 1.05 & 4.58 & 4.69 & 4.46 & 4.56 \\
\hline $\mathrm{EPA}+\mathrm{DHA}$ & 1.05 & 1.00 & 0.80 & 0.72 & $4 \cdot 17$ & 3.44 & 2.79 & 2.54 \\
\hline
\end{tabular}

AD:0S, AD:10S, AD:20S, AD:30S, adequate DHA supplemented with $0 \%, 10 \%, 20 \%$ and $30 \%$ digestible starch, respectively; ED:0S, ED:10S, ED:20S, ED:30S, excess DHA supplemented with $0 \%, 10 \%, 20 \%$ and $30 \%$ digestible starch, respectively. Nutrient content was evaluated per duplicate and the coefficient variation between values was below $3 \%$. 
$09.00 \mathrm{~h}$ the following day, the settled faeces and surrounding water were gently withdrawn from the base of the settling column into a large centrifuge bottle. The faeces were free of uneaten feed particles and considered to be a representative sample of the faeces produced throughout the $24 \mathrm{~h}$ period. After collection, the faeces were centrifuged at $5000 \mathrm{~g}$ for $10 \mathrm{~min}$ and the supernatant discarded. The faeces were then freeze-dried, ground and stored at $-20^{\circ} \mathrm{C}$ until analysis.

\section{Chemical analysis}

Feed ingredients, diets, fish carcasses and faecal samples were analysed for DM and ash according to Association of Official Analytical Chemists (1995), crude protein $(\mathrm{CP}, \% \mathrm{~N} \times 6 \cdot 25)$ using a Kjeltech autoanalyzer (Model \#1030; Tecator, Hoganas, Sweden) and gross energy (GE) using a Parr 1271 automated bomb calorimeter (Parr Instruments, Moline, IL, USA). Total carbohydrate was determined by difference. The digestion indicator was determined using the acid-insoluble ash indicator method of Atkinson et al. (1984). Lipid in the carcass was determined using an Ankom XT20 fat analyser (Ankom Technology, New York, USA) using petroleum ether, and the lipid content of the diets was analysed using an acid hydrolysis extraction (Association of Official Analytical Chemists, 1995).

\section{Glucose concentration in blood sample}

Plasma glucose concentration was measured for the first experiment using a ONE TOUCH II ${ }^{\circledR}$ glucose analyser (Johnson \& Johnson Co., Milpitas, CA, USA), and for the second feeding trial using a hexokinase/glucose 6-phosphate dehydrogenase (HK/G6PDH) kit (Thermo Trace Infinity Glucose Hexokinase reagent; Thermoelectron Co., Louisville, CO, USA).

\section{Hepatic composition and enzyme analyses}

For liver composition, liver samples collected from each tank were pooled and coarsely ground, divided into aliquots and frozen at $-20^{\circ} \mathrm{C}$ until analysis. DM, protein, ash and lipid were determined as described before. Glycogen was determined as described by Murat \& Serfaty (1974). Briefly, liver tissue (approximately $300 \mathrm{mg}$ ) was homogenized in $5 \mathrm{ml}$ $0 \cdot 1 \mathrm{M}$-citrate buffer $(\mathrm{pH} 4.5)$. Free glucose was determined using the HK/G6PDH method. Amyloglucosidase $(5 \mathrm{ml}$, $2 \mathrm{mg} / \mathrm{ml}$, Sigma A7255; Sigma, St Louis, MO, USA) was added to the homogenate and incubated for $2 \mathrm{~h}$ at $37^{\circ} \mathrm{C}$. Total glucose was determined after the incubation period. Glycogen was calculated by the difference between total glucose and free glucose.

For enzymatic analysis, the liver of each animal sampled was divided into two parts, individually snap-frozen in liquid $\mathrm{N}$ and stored at $-80^{\circ} \mathrm{C}$ until used. One part was used to assess glycolytic enzyme activities, and the other part to assess lipogenic enzyme activities. Measurement of glycolytic enzyme activities was performed following liver homogenization in 10 volumes of ice-cold buffer ( $80 \mathrm{~mm}$-Tris, 5 mM-EDTA, 2 mM-dithio-threitol, 1 mM-benzamidine, $1 \mathrm{mM}-4$-(2-aminoethyl) benzene sulfanyl fluoride; $\mathrm{pH} 7 \cdot 6$ ). The homogenate was centrifuged for $10 \mathrm{~min}$ at $1000 \mathrm{~g}$ at $4^{\circ} \mathrm{C}$, and supernatants were collected for enzyme analysis.
Glucokinase and $\mathrm{HK}$ activities were measured at $37^{\circ} \mathrm{C}$ by coupling the formation of ribulose 5-phosphate from glucose 6-phosphate to the reduction of NADP using purified G6PDH and 6-phosphogluconate dehydrogenase, according to the method of Panserat et al. (2000a). Total activity was measured in the presence of $1 \mathrm{~mm}$-glucose. One unit of enzyme activity was defined as the amount that phosphorylated $1 \mu \mathrm{M}$-glucose/min. In order to determine the activity of pyruvate kinase $(\mathrm{PK})$, the supernatant was centrifuged at 10 $000 \mathrm{~g}$ for $20 \mathrm{~min}$, and the resultant cytosolic fraction was used to measure enzyme activity. The procedure followed was that of Foster \& Moon (1985), monitoring the decrease in absorbance ( $\beta$-NAD, reduced form disappearance) using purified lactate dehydrogenase (Sigma) in excess as the coupling enzyme.

Assessment of lipogenic enzyme activities was performed following liver homogenization in three volumes of ice-cold buffer (20 mM-Tris-HCl, $250 \mathrm{mM}$-sucrose, 2 mM-EDTA, $100 \mathrm{mM}-\mathrm{NaF}, \quad 0.5 \mathrm{mM}$-phenyl methyl sulphonyl fluoride, $10 \mathrm{mM}$-beta-mercaptoethanol; $\mathrm{pH}$ 7.4). Homogenates were centrifuged at $15000 \mathrm{~g}$ at $4^{\circ} \mathrm{C}$ for $20 \mathrm{~min}$, and supernatants were collected for enzyme assays. G6PDH and malic enzyme (ME) activities were assessed using spectrophotometric procedures according to Bautista et al. (1988) and Ochoa (1955), respectively. Fatty acid synthase (FAS) activity was measured using an isotopic method as previously described by Hsu et al. (1969). In all the enzyme assays, the soluble hepatic protein content in the assayed reaction was determined by the method of Bradford (1976), using bovine serum albumin as standard. Enzyme activity units (IU), defined as micromoles of substrate converted to the product/ min at the assay temperature $\left(37^{\circ} \mathrm{C}\right)$, were expressed per milligram of hepatic soluble protein (specific activity).

\section{Statistical analysis}

Data were submitted to a two-way ANOVA with starch and DHA inclusion levels and their interactions as main effects by using the General Linear Model procedure (SAS, 1990) contained in the SAS computer software (SAS Institute Inc., Cary, NC, USA). Tukey's Studentized Range test was used when ANOVA main effects were significantly different. Differences were considered statistically significant at $P<0.05$.

The response of $\mathrm{N}$ retention efficiency ( $n$ 24) to increasing digestible starch supplementation was analysed according to the following second-order linear regression equation:

$$
Y=A+(B \times X)+\left(C \times X^{2}\right),
$$

where $Y$ is $\mathrm{N}$ retention efficiency and $\mathrm{X}$ is digestible starch supplementation. The level at which $95 \%$ of maximum response was achieved was considered optimal (Rodehutscord \& Pack, 1999). The statistical analysis was performed by software GraphPad Prism (Graph Pad Software, San Diego, CA, USA).

\section{Results}

\section{Chemical composition of the experimental diets}

Crude protein, ash, energy and DHA content were closed to the calculated values, except for lipid content. Diets 
supplemented with adequate DHA and excess DHA presented 0.4 and 1.8 (average) points less than the calculated values (Tables 2 and 3 ).

\section{Digestibility of components of experimental diets}

Starch supplementation slightly but significant reduced the digestibility of $\mathrm{CP}$, crude lipid, total carbohydrate and GE (Table 4), whereas DHA level affected the apparent digestibility of DM, CP, total carbohydrate and GE. A significant interaction between dietary starch and DHA supplementation was observed for the apparent digestibility of DM, CP, total carbohydrate and GE.

\section{Growth performance, feed intake, feed efficiency and dressed carcass yield}

Carbohydrate supplementation had significant effects on live body weight gain, thermal-unit growth coefficient, feed efficiency and dressed carcass yield (Table 5). Thermal-unit growth coefficient and feed intake increased linearly with the increasing levels of starch, whereas dressed carcass yield and feed efficiency were, in contrast, linearly reduced by the supplementation of digestible starch. Dietary DHA supplementation did not affect the performance of rainbow trout but reduced dressed carcass yield. Survival was not affected by the different treatments and, at the end of the experiment, was $90 \%$ overall.

\section{Hepatosomatic index and plasma glucose}

Hepatosomatic index and plasma glucose level increased linearly with the increasing levels of digestible starch (Table 5, Fig. 1). A significant effect of DHA supplementation on plasma glucose was observed in the second experiment: fish fed the diet with a high DHA level presented a higher plasma glucose concentration than those fed the lower DHA level. A significant interaction between DHA and starch supplementation was observed in the second experiment for hepatosomatic index (data not shown) and plasma glucose.

\section{Carcass and liver composition}

The moisture, $\mathrm{CP}$, crude lipid and GE contents of the carcass were significantly affected by digestible starch supplementation (Table 6). Increasing levels of starch slightly decreased the protein and moisture contents, and increased the lipid and GE contents of the carcass. Increasing dietary DHA significantly decreased lipid and GE in carcass, and increased the moisture content (Fig. 2).

Dietary carbohydrate inclusion reduced moisture, $\mathrm{CP}$, crude lipid and ash content in liver samples and increased glycogen content (Table 7). DHA supplementation level had an effect on the glycogen and protein contents of fish liver: fish fed diet rich in DHA and starch achieved the lowest glycogen and the highest protein contents in comparison to those fed adequate DHA and high starch supplementation levels. A significant interaction between starch and DHA levels was observed for the moisture, $\mathrm{CP}$, ash and glycogen contents of liver.

\section{Nutrient retention efficiencies}

The retention of $\mathrm{N}$, lipid and energy increased with the increasing levels of starch; the best $\mathrm{N}$ retention for diets supplemented with adequate DHA was observed with the highest starch inclusion level, whereas for the diets with excess DHA, the best were those containing $20 \%$ and $30 \%$ of digestible starch (Table 8 ). The optimal inclusion level of digestible starch in which $\mathrm{N}$ retention efficiency was improved was calculated to $10 \%$ supplementation level (Fig. 2). DHA supplementation did not affect nutrient retention except for lipid retention, which was reduced by the excess DHA.

\section{Key enzymes of hepatic metabolism}

Dietary carbohydrates enhanced the activity of the glycolytic enzymes glucokinase and PK, but not HK (Table 9). Glucokinase and PK activities were increased approximately $70-$ and 2.5-fold, respectively. DHA level significantly reduced the activity of PK: fish fed the ED:30S diet presented

Table 4. Apparent digestibility coefficients $\dagger$ of nutrients of the diets supplemented with different levels of digestible starch and DHA

\begin{tabular}{|c|c|c|c|c|c|}
\hline Experimental diet & DM (\%) & Crude protein (\%) & Crude lipid (\%) & Total carbohydrate (\%) & Gross energy (\%) \\
\hline \multicolumn{6}{|c|}{ Diets with adequate DHA } \\
\hline AD:OS & $90^{\mathrm{a}}$ & $95^{\mathrm{b}}$ & $97^{\mathrm{b}}$ & $69^{b}$ & $95^{\mathrm{a}}$ \\
\hline AD:30S & $91^{\mathrm{b}}$ & $94^{\mathrm{b}}$ & $95^{\mathrm{a}}$ & $94^{\mathrm{c}}$ & $95^{a}$ \\
\hline SEM $\ddagger$ & 0.3 & 0.1 & 0.3 & $4 \cdot 0$ & 0.2 \\
\hline \multicolumn{6}{|c|}{ Diets with excess DHA } \\
\hline ED:OS & $90^{\mathrm{a}}$ & $95^{\mathrm{b}}$ & $97^{\mathrm{b}}$ & $55^{\mathrm{a}}$ & $95^{\mathrm{b}}$ \\
\hline ED:30S & $89^{\mathrm{a}}$ & $93^{a}$ & $95^{a}$ & $92^{\mathrm{c}}$ & $93^{a}$ \\
\hline SEM & 0.3 & 0.3 & 0.3 & $6 \cdot 0$ & 0.3 \\
\hline \multicolumn{6}{|l|}{ Main effects } \\
\hline Starch & NS & $* * *$ & *** & $\star * *$ & ** \\
\hline $\mathrm{DHA}$ & * & $* * *$ & NS & ** & ** \\
\hline Interaction & * & ** & NS & * & * \\
\hline
\end{tabular}

\footnotetext{
AD:0S, AD:30S, adequate DHA supplemented with $0 \%$ and $30 \%$ digestible starch, respectively; ED:0S, ED:30S, excess DHA supplemented with $0 \%$ and $30 \%$ digestible starch, respectively.

$\mathrm{a}, \mathrm{b}, \mathrm{c}$ Values with unlike superscript letters were significantly different $(P<0.05)$

${ }^{\star} P<0.05 ;{ }^{* \star} P<0.01 ;{ }^{* *} P<0.001 ;$ NS, not statistically significant, $P>0.05$.

†Apparent digestibility coefficients: [1 - ((\%) nutrient (or kJ/g GE) of faeces / (\%) nutrient (or kJ/g GE) of diet) $\times((\%)$ digestion indicator (acid-insoluble ash) of diet / (\%) digestion indicator (acid-insoluble ash) of faeces)] $\times 100$ (Cho et al. 1982).

$\ddagger$ Pooled SEM; $n 8$.
} 
Table 5. Performance of rainbow trout (initial body weight $79 \pm 2$ gmean \pm SD) fed diets supplemented with different levels of digestible starch and DHA for 12 weeks at $15^{\circ} \mathrm{C}$ (trial 1)

\begin{tabular}{|c|c|c|c|c|c|c|c|}
\hline Experimental diet & LBWG (g/fish) & TGC (\%) & Feed intake (g DM/fish) & FE (Gain:feed) & BDFI (g DM/fish) & DCY (\%) & HSI (\%) \\
\hline \multicolumn{8}{|c|}{ Diets with adequate DHA } \\
\hline AD:OS & $162^{a}$ & $0.154^{a}$ & $115^{\mathrm{a}}$ & $1 \cdot 41^{\mathrm{b}}$ & $115^{\mathrm{a}}$ & $91^{\mathrm{b}}$ & $1 \cdot 0^{\mathrm{a}}$ \\
\hline AD:20S & $171^{\mathrm{a}, \mathrm{b}}$ & $0 \cdot 160^{a, b}$ & $142^{c}$ & $1 \cdot 20^{a, b}$ & $114^{\mathrm{a}}$ & $92^{\mathrm{b}}$ & $1.6^{\mathrm{b}}$ \\
\hline AD:30S & $208^{c}$ & $0.185^{\mathrm{b}}$ & $179^{d}$ & $1 \cdot 16^{\mathrm{a}}$ & $126^{\mathrm{b}}$ & $89^{a, b}$ & $1 \cdot 8^{\mathrm{c}}$ \\
\hline SEM† & 6 & 0.004 & 25 & 0.1 & 5 & 0.4 & 0.05 \\
\hline \multicolumn{8}{|c|}{ Sianificance contrastł } \\
\hline Quadratic & NS & NS & $* * *$ & NS & $* * *$ & NS & NS \\
\hline \multicolumn{8}{|c|}{ Diets with excess DHA } \\
\hline ED:OS & $160^{\mathrm{a}}$ & $0.153^{a}$ & $119^{a}$ & $1 \cdot 35^{a, b}$ & $119^{a}$ & $90^{a, b}$ & $1.0^{\mathrm{a}}$ \\
\hline ED:10S & $172^{\mathrm{a}, \mathrm{b}}$ & $0 \cdot 160^{\mathrm{a}, \mathrm{b}}$ & $129^{\mathrm{b}}$ & $1 \cdot 33^{a, b}$ & $116^{a, b}$ & $90^{a, b}$ & $1 \cdot 1^{\mathrm{a}}$ \\
\hline ED:20S & $194^{a, b, c}$ & $0.175^{\mathrm{a}, \mathrm{b}}$ & $144^{\mathrm{C}}$ & $1 \cdot 35^{a, b}$ & $115^{\mathrm{a}, \mathrm{b}}$ & $88^{a}$ & $1.5^{\mathrm{b}}$ \\
\hline ED:30S & $204^{\mathrm{b}, \mathrm{c}}$ & $0.182^{\mathrm{b}}$ & $180^{\mathrm{d}}$ & $1 \cdot 13^{a}$ & $126^{\mathrm{b}}$ & $88^{a}$ & $1.8^{\mathrm{C}}$ \\
\hline SEM & 6 & 0.004 & 24 & $0 \cdot 2$ & $5 \cdot 0$ & 0.4 & 0.05 \\
\hline \multicolumn{8}{|c|}{ Significance contrast } \\
\hline Quadratic & NS & NS & $* \star *$ & * & $* \star *$ & NS & NS \\
\hline \multicolumn{8}{|l|}{ Main effects } \\
\hline Starch & $\star \star \star *$ & 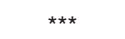 & $\star \star \star \star ~$ & $\star \star \star \star ~$ & $\star \star \star \star$ & * & $\star \star \star \star ~$ \\
\hline $\mathrm{DHA}$ & NS & NS & * & NS & * & ** & NS \\
\hline Interaction & NS & NS & NS & NS & NS & NS & NS \\
\hline
\end{tabular}

AD:0S, AD:10S, AD:20S, AD:30S, adequate DHA supplemented with 0\%, 10\%, $20 \%$ and $30 \%$ digestible starch, respectively; ED:0S, ED:10S, ED:20S, ED:30S, excess DHA supplemented with $0 \%, 10 \%, 20 \%$ and $30 \%$ digestible starch, respectively.

LBWG, live body weight gain ((FBW / final number of fish) - (IBW / initial number of fish)); TGC, thermal-unit growth coefficient $\left(100 \times\left[\left(F B W^{1 / 3}-I B W^{1 / 3}\right) \times(\text { sum } T \times D)^{-1}\right]\right)$; Feed intake $(\mathrm{g} \mathrm{DM} /(\Sigma \mathrm{fish} / \mathrm{d})) \times($ number of days $\times 100))$; FE, feed efficiency (live body weight gain $(\mathrm{g}) /$ feed intake $(\mathrm{g}$ DM)); BDFI, basal diet intake $($ basal feed intake $\mathrm{g}$ $\mathrm{DM} / \Sigma($ fish $/ \mathrm{d}) \times($ number of days $\times 100))$; DCY, dressed carcass yield ((dressed carcass weight / live body weight) $\times 100)$ ); HSI, hepatosomatic index; FBW, final body weight (g); IBW, initial body weight $(\mathrm{g})$; sum $T \times D\left(\right.$ sum $\left.{ }^{\circ} \mathrm{C} \times \mathrm{d}\right)$.

a,b,c Values with unlike superscript letters were significantly different $(P<0.05)$

${ }^{\star} P<0.05 ;{ }^{\star \star} P<0.01 ;{ }^{\star \star \star} P<0.001$; NS, not statistically significant, $P>0.05$.

†Pooled SEM; $n 12$.

¥Significance of the orthogonal linear and quadratic contrasts of dependent variables across diets.

low PK activity $(29 \mathrm{IU} / \mathrm{g})$ in comparison to those fed the $\mathrm{AD}: 30 \mathrm{~S}$ diet $(43 \mathrm{IU} / \mathrm{g})$, but those fed free-carbohydrate diets, with either a low or a high DHA inclusion level, presented similar PK activity $(15.3 v .15 .0 \mathrm{IU} / \mathrm{g})$. The activity of the lipogenic enzyme G6PDH was increased approximately 2-fold by digestible starch supplementation. ME enzyme was reduced with a high starch intake, but when the values were expressed as specific activity (IU/mg protein), no significant effect was observed. A small but significant effect of starch on the specific activity of FAS was found, but no effect of DHA was observed.

\section{Discussion}

\section{Nutrient digestibility}

Apparent digestibility coefficients for DM, protein and GE observed in the present study are similar to those reported previously in rainbow trout fed high-quality ingredients (Azevedo et al. 2004; Encarnação et al. 2004).

\section{Growth trial and nutrient retention}

The significant increase in weight gain and the reduction of dressed carcass yield with increasing levels of starch agrees with what has been previously reported for rainbow trout (Hilton \& Atkinson, 1982; Bergot \& Breque, 1983; Hilton et al. 1987; Brauge et al. 1994; Hillestad \& Johnsen, 1994;
Jobling et al. 1998; Suárez et al. 2002; Azevedo et al. 2004). Digestible energy from digestible carbohydrates appeared to be well retained (having a good net energy value) as efficiency of digestible energy retention was similar across treatments. Starch levels of up to $10-12 \%$ appear to effectively spare dietary amino acids from being catabolized by allowing a greater $\mathrm{N}$ gain and an improved efficiency of digestible $\mathrm{N}$ retention. These results are consistent with those of a number of studies (Pieper \& Pfeffer, 1980; Kim \& Kaushik, 1992; Médale et al. 1994). These observations contrast, however, with those of Beamish et al. (1986), Hilton et al. (1987) and Bureau et al. (1998), who observed that digestible carbohydrate supplementation did not improve the efficiency of $\mathrm{N}$ utilization and that digestible energy from digestible carbohydrate was poorly retained by rainbow trout.

Differences in the results from diverging studies probably lie in the differences in composition of the diet used. Protein levels, amino acid composition, level of non-protein energyyielding nutrients (lipids, carbohydrates) and digestible protein to digestible energy ratio are known to affect $\mathrm{N}$ retention efficiency and potentially the net energy content of the diet. In the present study, the basal diets had very high CP $(69 \%)$, moderate lipid (19\%) and very low digestible carbohydrate $(<4 \%)$ levels. A digestible starch supplementation of $10 \%$ to these basal diets allowed $\mathrm{N}$ retention efficiency to improve from $38 \%$ to $43 \%$, although a further increase in digestible starch supplementation did not significantly affect $\mathrm{N}$ retention efficiency. Bureau et al. (1998) observed no improvement in N 


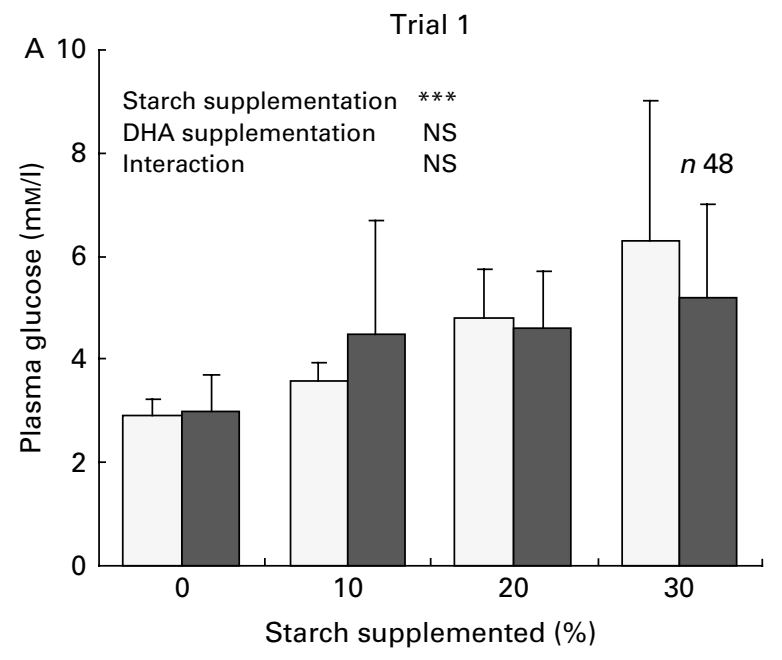

Trial 2

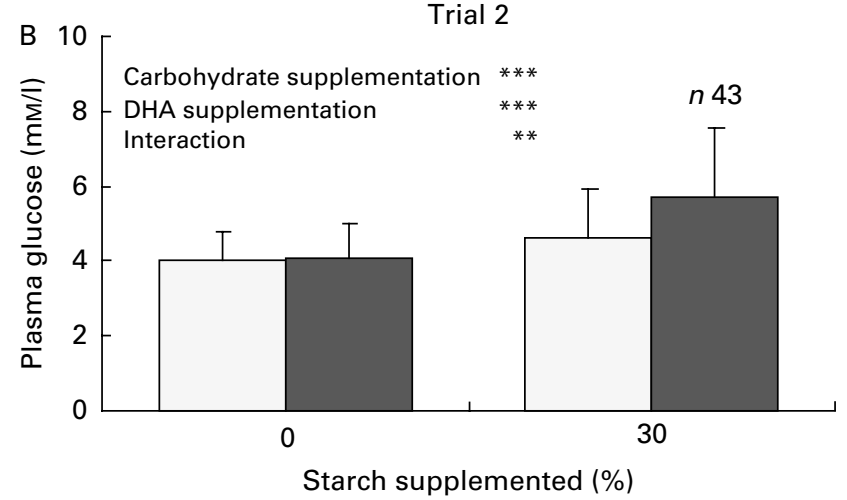

Fig. 1. Plasma glucose in rainbow trout fed increasing levels of digestible starch and two levels of dietary DHA. ( $\square$ ) adequate DHA, (ם) excess DHA. ${ }^{\star \star \star} P<0.001$. retention efficiency (44\%) when supplementing a lower-CP basal diet $(430 \mathrm{~g} / \mathrm{kg} \mathrm{CP}, 160 \mathrm{~g} / \mathrm{kg}$ lipids, $160 \mathrm{~g} / \mathrm{kg}$ digestible carbohydrate) with high levels of digestible starch. In contrast, Pieper \& Pfeffer (1980) and Kim \& Kaushik (1992) observed an improvement of $\mathrm{N}$ retention efficiency (from $38 \%$ to $41 \%$ ) in response to increasing digestible carbohydrates in fish fed diets containing $410-480 \mathrm{~g} / \mathrm{kg} \mathrm{CP}$ and relatively low (80$100 \mathrm{~g} / \mathrm{kg}$ ) lipid levels. It is evident from the results of the present study that, at levels between 100 and $200 \mathrm{~g} / \mathrm{kg}$ of the diet, digestible carbohydrate can be effectively utilized as an energy source to support protein deposition, when a significant amount of digestible amino acids are catabolized for energy release (preferential catabolism), i.e. when $\mathrm{N}$ retention efficiency is less than $40-45 \%$ (rainbow trout weighing 200$400 \mathrm{~g}$ fed a diet with well-balanced amino acid profile). At a very high level of digestible starch intake, it is suggested that the ability of rainbow trout to synthesize lipid and glycogen from glucose may be exceeded, and absorbed carbohydrate is wasted metabolically (Bureau et al. 1998).

\section{Plasma glucose, liver size and glycogen content}

The significant increases in plasma glucose, body lipid and glycogen content in fish liver caused by the increasing levels of starch are in agreement with those observed previously in mammals (Iritani, 1992; Towle et al. 1997) and fish (Lin et al. 1977a,b; Walton \& Cowey, 1982; Kaushik et al. 1989; Médale et al. 1994; Brauge et al. 1995; Tranulis et al. 1996; Dias et al. 1998; Panserat et al. 2000a,b, 2001a,b; Barroso et al. 2001; Capilla et al. 2003). Feeding diets rich in PUFA to rats and birds decreased body fat and glycogen content and occasionally increased plasma glucose (Rustan et al. 1993; Jump et al. 1994; Sanz et al. 2000a,b;

Table 6. Composition of the whole body of rainbow trout fed diets supplemented with different levels of digestible starch and DHA for 12 weeks at $15^{\circ} \mathrm{C}$ (trial 1)



AD:0S, AD:10S, AD:20S, AD:30S, adequate DHA supplemented with 0\%, 10\%, 20\% and 30\% digestible starch, respectively; ED:0S, ED:10S, ED:20S, ED:30S, excess DHA supplemented with $0 \%, 10 \%, 20 \%$ and $30 \%$ digestible starch, respectively. Initial carcass composition: $70.8 \%$ moisture, $16 \cdot 1 \%$ crude protein, $9.5 \%$ crude lipid, $2.4 \%$ ash and $7.9 \mathrm{MJ} / \mathrm{kg}$ gross energy.

a,b,c Values with unlike superscript letters were significantly different $(P<0.05)$

${ }^{\star} P<0.05 ;{ }^{\star \star} P<0.01 ;{ }^{\star \star \star} P<0.001$; NS, not statistically significant, $P>0.05$.

†Pooled SEM; $n 12$.

$\ddagger$ Significance of the orthogonal linear and quadratic contrasts of dependent variables across diets. 


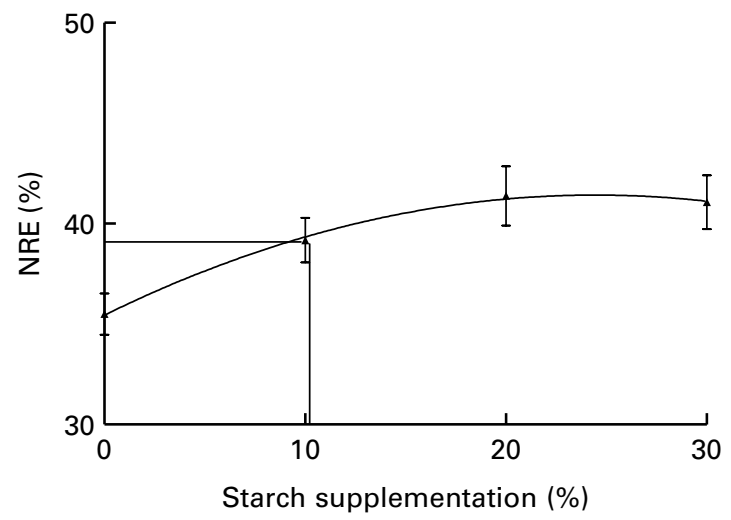

Fig. 2. Nitrogen retention efficiency (NRE) of rainbow trout in response to increasing levels of digestible starch.

Gaíva et al. 2001; Crespo \& Esteve-Garcia, 2001, 2002a,b; Mashek \& Grummer, 2003). Fish fed excess DHA presented lower body lipid in comparison to those fed adequate DHA. In contrast, the lipid content of liver samples was not affected by the dietary DHA content, but the combination of high dietary starch and DHA decreased the glycogen content of liver. Rustan et al. (1993) reported higher carbohydrate oxidation levels with a concomitant reduction in liver glycogen and higher plasma glucose in rats fed diets supplemented with an EPA + DHA concentrate. The results from this study indicate that dietary DHA slightly alters lipid and carbohydrate metabolism in rainbow trout.

\section{Enzymatic activity}

The enhancement of enzyme activity by increasing levels of dietary starch observed in the present study is in accordance with what has previously been reported in mammals (Iritani, 1992; Towel et al. 1997) and fish (Lin et al. 1977a,b; Walton \& Cowey, 1982; Jürss et al. 1985; Kaushik et al. 1989; Médale et al. 1994; Brauge et al. 1995; Shimeno et al. 1996; Tranulis et al. 1996; Dias et al. 1998; Panserat et al. 2000a,b, 2001a; Barroso et al. 2001; Gélineau et al. 2001;
Capilla et al. 2003). Rats are more sensitive to dietary lipids than are fish. The inclusion of $30-40 \mathrm{~g} / \mathrm{kg}$ lipids led to a significant inhibition of enzyme activity (Chilliard, 1993), whereas fish required high lipid inclusion levels $(>20 \%)$ (Jürss et al. 1985; Arnesen et al. 1993; Brauge et al. 1994; Dias et al. 1998; Rollin et al. 2003). In contrast, some other studies have suggested that dietary carbohydrates and lipids do not change the activities of some enzymes involved in lipid and carbohydrate metabolism. Likimani \& Wilson (1982), Fynn-Aikins et al. (1992), Gélineau et al. (2001) and Panserat et al. (2001a) reported that the activities of HK and ME were not affected by dietary carbohydrates or lipids.

There is an indication that nutrient ratio somehow modulates the enzyme activity. Iritani (1992) reported that re-feeding diets rich in carbohydrates to rats enhanced acetyl-CoA carboxylase (ACoAC) activity, whereas FAS activity was induced by dietary carbohydrates, although both protein and carbohydrates were required to achieve a substantial increase. These same changes have been also found in fish. Alvarez et al. (2000) reported that glucose-protein proportion changed $\mathrm{ME}$ and ACoAC activities, whereas glucose-fat relative amount modified ME, ATP citrate lyase (ACL), ACoAC and FAS activities, and protein-fat percentage altered G6PD-, ME; ACL and FAS activities in rainbow trout hepatocytes.

On the other hand, the carbohydrate source also influenced the activities of these enzymes. D-Glucose and its derivates highly inhibited glucose 6-phosphatase (Ikeda \& Shimeno, 1967), whereas fructose did not affect HK activity (Panserat et al. 2001a). G6PD- and 6-phosphogluconate dehydrogenase activities decreased with the increasing levels of oats, whereas a maize/oat mixture reduced G6PDA, 6-phosphogluconate dehydrogenase and ME activities (Arnesen et al. 1993). In the present study, dietary starch enhanced some of the enzymes tested without affecting the activities of HK and ME.

The absence of an effect of DHA level on the activity of hepatic enzymes contradicts what has been observed in rats (Clarke \& Abraham, 1992; Clarke \& Jump, 1992; Clarke, 1993; Rustan et al. 1993; Jump et al. 1994; Mashek \& Grummer, 2003) and fish (Alvarez et al. 2000; Menoyo et al. 2003). Differences in results can be linked to the nutrient composition

Table 7. Chemical composition of rainbow trout livers fed diets supplemented with different levels of digestible starch and DHA for 12 weeks at $16^{\circ} \mathrm{C}$ (trial 2)

\begin{tabular}{|c|c|c|c|c|c|}
\hline Experimental diet & Moisture (\%) & Crude protein (\%) & Crude lipid (\%) & Ash (\%) & Glycogen (\%) \\
\hline \multicolumn{6}{|c|}{ Diets with adequate $\mathrm{DHA}$} \\
\hline AD:OS & $75 \cdot 6^{c}$ & $14 \cdot 7^{\mathrm{c}}$ & $4 \cdot 0^{b}$ & $1 \cdot 3^{\mathrm{a}}$ & $1 \cdot 2^{\mathrm{a}}$ \\
\hline$A D: 30 S$ & $73 \cdot 4^{a}$ & $11 \cdot 1^{\mathrm{a}}$ & $3 \cdot 1^{\mathrm{a}}$ & $1 \cdot 1^{\mathrm{a}}$ & $3 \cdot 4^{\mathrm{C}}$ \\
\hline SEM† & $1 \cdot 2$ & $2 \cdot 0$ & 0.5 & $0 \cdot 1$ & 0.3 \\
\hline \multicolumn{6}{|c|}{ Diets with excess DHA } \\
\hline ED:OS & $75 \cdot 4^{c}$ & $14 \cdot 8^{\mathrm{c}}$ & $4 \cdot 0^{\mathrm{b}}$ & $1 \cdot 3^{\mathrm{a}}$ & $1 \cdot 2^{\mathrm{a}}$ \\
\hline ED:30S & $74 \cdot 1^{\mathrm{b}}$ & $12 \cdot 8^{\mathrm{b}}$ & $3 \cdot 6^{\mathrm{b}}$ & $1 \cdot 2^{\mathrm{a}}$ & $2 \cdot 4^{\mathrm{b}}$ \\
\hline SEM† & 0.7 & $1 \cdot 2$ & 0.3 & $0 \cdot 1$ & 0.1 \\
\hline \multicolumn{6}{|l|}{ Main effects } \\
\hline Starch & 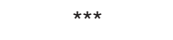 & * & ** & ** & 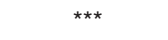 \\
\hline $\mathrm{DHA}$ & NS & $* \star \star$ & NS & NS & $\star \star \star$ \\
\hline Interaction & $\star \star$ & * & NS & * & $\star \star *$ \\
\hline
\end{tabular}

AD:0S, AD:10S, AD:20S, AD:30S, adequate DHA supplemented with $0 \%, 10 \%, 20 \%$ and $30 \%$ digestible starch, respectively; ED:0S, ED:10S, ED:20S, ED:30S, excess DHA supplemented with $0 \%, 10 \%, 20 \%$ and $30 \%$ digestible starch, respectively.

${ }^{a, b, c}$ Values with unlike superscript letters were significantly different $(P<0.05)$.

${ }^{\star} P<0.05 ;{ }^{\star *} P<0.01 ;{ }^{* \star} P<0.001$; NS, not statistically significant, $P>0.05$.

†Pooled SEM; $n 6$. 
M. Tapia-Salazar et al.

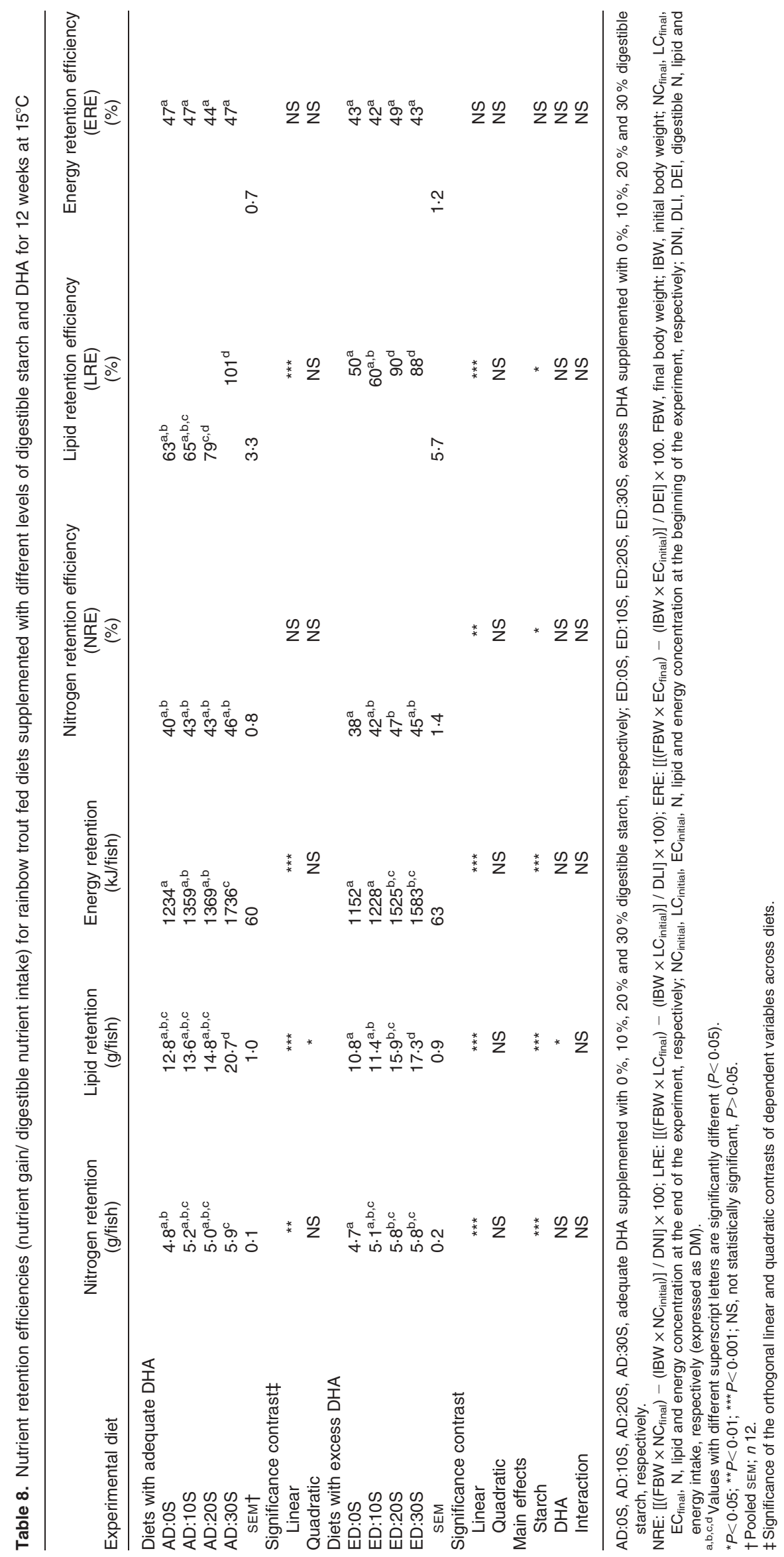


of the experimental diets. Alvarez et al. (2000) observed that EPA strongly inhibited ME, ACL and FAS, whereas DHA inhibited G6PD- and ACoAC activity. Menoyo et al. (2003) observed that the inclusion levels of $n-3$ fatty acids decreased the activity of G6PD-, L-3-hydroxyacyl-CoA dehydrogenase and ME. This author used diets rich in lipids (38\%), whereas in the present study, dietary lipid made up $18 \%$ of the basal diets and $12 \%$ of the diluted diets. It seems that the carbohydrates and lipids contents of the diets are greatly affected by carbohydrate and lipid metabolism, although the reduction in hepatic lipid and glycogen content observed in fish fed high levels of DHA suggests that DHA may have a small effect on the flux of glucose or lipids or their deposition in certain tissues.

In conclusion, increased digestible starch intake increased protein and lipid retention and enhanced the activity of the glycolytic and lipogenic enzymes. Feeding a high DHA level did not affect the performance of rainbow trout, their nutrient retention efficiencies and the activity of glycolytic and lipogenic enzymes compared with feeding a lower, but nutritionally adequate, level of DHA. These observations, combined with the slight reductions in lipid and glycogen content observed with increasing DHA intake, suggest only a small and marginal effect of dietary DHA on glucose metabolism in fish fed nutritionally adequate diets.

\section{Acknowledgements}

This study was supported by a Discovery Grant from the National Science and Engineering Research Council (NSERC) of Canada. Sincere thanks to Martin Feed Mills (Elmira, Ontario, Canada), Tokyo University of Fisheries (Tokyo, Japan), and Ocean Nutrition (Halifax, Nova Scotia, Canada) for providing ingredients used in this study. The technical assistance of Matthew Bancroft, Ursula Wehkamp, Christiane Vachot, and Laurence Larroquet is acknowledged.

\section{References}

Alvarez MJ, Díez A, López-Bote C, Gallego M \& Bautista JM (2000) Short-term modulation of lipogenesis by macronutrients in rainbow trout (Oncorhynchus mykiss) hepatocytes. Br J Nut 84, 619-628.

Arnesen P, Krogahl A \& Kristiansen IO (1993) Lipogenic enzyme activities in liver of Atlantic salmon (Salmo salar, L.). Comp Biochem Physiol 105B, 541-546.

Association of Official Analytical Chemists (1995) Official Methods of Analysis of AOAC International. Agricultural Chemicals; Contaminants, Drugs, 16th ed. Arlington, VA: AOAC International.

Atkinson JL, Hilton JW \& Slinger SJ (1984) Evaluation of acid-insoluble ash as an indicator of feed digestibility in rainbow trout (Salmo gairdneri). Can J Fish Aquat Sci 41, 1384-1386.

Azevedo PA, Leeson S, Cho CY \& Bureau DP (2004) Growth, nitrogen and energy utilization of juveniles from four salmonid species: diet, species and size effects. Aquaculture 234, 393-414.

Barroso JB, Peragón J, García-Salguero L, delaHiguera M \& Lupiáñez JA (2001) Carbohydrate deprivation reduces NADPHproduction in fish liver but not in adipose tissue. Int J Biochem Cell Biol 33, 785-796.

Bautista JM, Garrido-Pertierra A \& Soler G (1988) Glucose-6-phosphate dehydrogenase from Dicentrarchus labrax liver: kinetic mechanism and kinetics of NADPH inhibition. Biochim Biophys Acta 967, 354-363. 
Beamish FWH, Hilton JW, Niimi E \& Slinger SJ (1986) Dietary carbohydrate and growth, body composition and heat increment in rainbow trout (Salmo gairdneri). Fish Physiol Biochem 64, $543-547$.

Bergot F (1979) Carbohydrate in rainbow trout diets: effects of the levels and source of carbohydrate and the numbers of meals on growth and body composition. Aquaculture 18, 157-167.

Bergot F \& Breque J (1983) Digestibility of starch by rainbow trout: effects of the physical state of starch and of the intake level. Aquaculture 34, 203-212.

Bradford MM (1976) A rapid and sensitive method for the quantification of microgram quantities of protein utilizing the principle of protein-dye binding. Anal Biochem 72, 248-254.

Brauge C, Corraze G \& Médale F (1995) Effect of dietary levels of carbohydrate and lipid on glucose oxidation and lipogenesis from glucose in rainbow trout, Onchorhynchus mykiss, reared in freshwater or in seawater. Comp Biochem Physiol 111A, 117-124.

Brauge C, Médale F \& Corraze G (1994) Effect of dietary carbohydrate levels on growth, body composition and glycemia in rainbow trout, Oncorhynchus mykiss, reared in seawater. Aquaculture 123, 109-120.

Bureau DP, Kirkland JB \& Cho CY (1998) The partitioning of energy from digestible carbohydrate by rainbow trout (Oncorhynchus mykiss). In Energy Metabolism of Farm Animals, pp. 163-166 [KJ McCracken, EF Unsworth and ARG Wylie, editors]. Wallingford, UK: CAB International.

Canadian Council on Animal Care (1984) Guide to the Care and Use of Experimental Animals, vol. 2. Ottowa, Ontario: Canadian Council on Animal Care.

Capilla E, Médale F, Navarro I, Panserat S, Vachot Ch, Kaushik S \& Gutiérrez J (2003) Muscle insulin binding and plasma levels in relation to liver glucokinase activity, glucose metabolism and dietary carbohydrates in rainbow trout. Regul Pept 110, 123-132.

Chilliard Y (1993) Dietary fat and adipose tissue metabolism in ruminants, pigs and rodents: a review. J Dairy Sci 76, 3897-3931.

Cho CY, Slinger SJ \& Bayley HS (1982) Bioenergetics of salmonid fishes: energy intake, expenditure and productivity. Comp Biochem Physiol 73B, 25-41.

Clarke SD (1993) Regulation of fatty acid synthase gene expression: an approach for reducing fat accumulation. J Anim Sci 71, $1957-1965$.

Clarke SD (2000) Polyunsaturated fatty acid regulation of gene transcription: a mechanism to improve energy balance and insulin resistance. Br J Nutr 83, S59-S66.

Clarke SD \& Abraham S (1992) Gene expression: nutrient control of pre- and posttranscriptional events. FASEB J 6, 3146-3152.

Clarke SD \& Jump DB (1992) Regulation of hepatic gene expression by dietary fats: a unique role for polyunsaturated fatty acids. In Nutrition and Gene Expression, pp. 227-246 [CD Berdanier and JL Hargrove, editors]. Boca Raton, FL: CRC Press.

Crespo N \& Esteve-Garcia E (2001) Dietary fatty acid profile modifies abdominal fat deposition in broiler chickens. Poult Sci 80, 71-78.

Crespo N \& Esteve-Garcia E (2002a) Nutrient and fatty acid deposition in broilers fed different dietary fatty acid profiles. Poult Sci 81, 1533-1542.

Crespo N \& Esteve-Garcia E (2002b) Dietary linseed oil produces lower abdominal fat deposition but higher de novo fatty acid synthesis in broiler chickens. Poult Sci 81, 1555-1562.

Dias J, Alvarez MJ, Diez A, Arzel J, Corraze G, Bautista JM \& Kaushik SJ (1998) Regulation of hepatic lipogenesis by dietary protein/energy in juvenile European seabass (Dicentrarchus labrax). Aquaculture 161, 169-186.

Encarnação P, deLange C, Rodehutscord M, Hoehler D, Bureau W \& Bureau DP (2004) Diet digestible energy content affects lysine utilization, but not dietary lysine requirements of rainbow trout (Oncorhynchus mykiss) for maximum growth. Aquaculture 235, $569-586$.
Fynn-Aikins K, Hung SSO, Liu W \& Li H (1992) Growth, lipogenesis and liver composition of juvenile white sturgeon fed different levels of D-glucose. Aquaculture 105, 61-72.

Foster GD \& Moon TW (1985) Enzyme activities in Atlantic hagfish, Myxine glutinosa: changes with capacity and food deprivation. Can J Zool 64, 1080-1085.

Gaíva MH, Couto RC, Oyama LM, Couto GE, Silveira VL, Riberio EB \& Nascimento CM (2001) Polyunsaturated fatty acid-rich diets: effect on adipose tissue metabolism in rats. Br J Nutr 86, 371-377.

Gélineau A, Corraze G, Boujard T, Larroquet L \& Kaushik S (2001) Relation between dietary lipid level and voluntary feed intake, growth nutritent, lipid deposition and hepatic lipogenesis in rainbow trout. Reprod Nutr 41, 487-503.

Gómez-Requeni P, Mingarro M, Kirchner S, et al. (2003) Effects of dietary amino acid profile on growth performance, key metabolic enzymes and somatotropic axis responsiveness of gilthead sea bream (Sparus aurata). Aquaculture 220, 749-767.

Helland SJ \& Grisdale-Helland B (1998) The influence of dietary carbohydrate and protein levels on energy and nitrogen utilization of Atlantic salmon in seawater. In Energy Metabolism of Farm Animals, pp. 391-394 [KJ McCracken, EF Unsworth and ARG Wylie, editors]. Wallingford, UK: CAB International.

Hemre GI, Mommsen TP \& Krogahl $\AA$ (2002) Carbohydrates in fish nutrition: effects on growth, glucose metabolism and hepatic enzymes. Aquaculture Nutr 8, 175-194.

Hemre GI \& Storebakken T (2000) Tissue and organ distribution of ${ }^{14} \mathrm{C}$-activity in dextrin-adapted Atlantic salmon after oral administration of radiolabelled ${ }^{14} \mathrm{C}_{1}$-glucose. Aquac Nutr 6, 229-234.

Hillestad M \& Johnsen F (1994) High-energy/low-protein diets for Atlantic salmon: effects on growth, nutrient retention and slaughter quality. Aquaculture 124, 109-116.

Hilton JW \& Atkinson JL (1982) Responses of rainbow trout to increased levels of available carbohydrate in practical trout diets. Br J Nutr 47, 597-607.

Hilton JW, Atkinson JL \& Slinger SJ (1987) Evaluation of the net energy value of glucose (cerelose) and maize starch in diets for rainbow trout (Salmo gairdneri). Br J Nutr 58, 453-461.

Hsu RY, Butterworth PHW \& Porter JW (1969) Pigeon liver fatty acid synthetase. In Methods in Enzymology, vol. 14, pp. 33-39 [JM Lowenstein, editor]. New York: Academic Press.

Ikeda S \& Shimeno S (1967) Studies on glucose-6-phosphatase of aquatic animals. I. Properties of hepatic glucose-6-phosphatase of fishes. Bull Jap Soc Sci Fish 33, 104-111.

Iritani N (1992) Nutritional and hormonal regulation of lipogenicenzyme gene expression in rat liver. Eur J Biochem 205, 433-442.

Jobling M, Koskela J \& Savolainen R (1998) Influence of dietary fat level and increased adiposity on growth and fat deposition in rainbow trout, Oncorhynchus mykiss (Walbaum). Aquac Res 29, 601-607.

Jump DB, Clarke SD, Thelen A \& Liimatta M (1994) Coordinate regulation of glycolytic and lipogenic gene expression by polyunsaturated fatty acids. J Lipid Res 35, 1076-1084.

Jürss K, Bittorf T \& Vökler TH (1985) Influence of salinity and ratio of lipid to protein in diets on certain enzyme activities in rainbow trout (Salmo gairdneri Richardson). Comp Biochem Physiol 81B, 73-79.

Kaushik SJ, Medale F, Fauconneau B \& Blanc D (1989) Effect of digestible carbohydrates on protein/energy utilization and glucose metabolims in rainbow trout (Salmo gairdneri R.). Aquaculture 79, 63-74.

Kaushik S \& Oliva-Teles A (1985) Effect of digestible energy on nitrogen and energy balance in rainbow trout. Aquaculture 50, 89-101.

Kim JD \& Kaushik SJ (1992) Contribution of digestible energy from carbohydrates and estimation of protein/energy requirements for growth of rainbow trout (Oncorhynchus mykiss). Aquaculture 106, $161-169$. 
Likimani TA \& Wilson RP (1982) Effects of diet on lipogenic enzyme activities in channel catfish hepatic and adipose tissue. $J$ Nutr 112, 112-117.

Lin H, Romsos DR, Tack PI \& Leveille GA (1977a) Effects of fasting and feeding various diets on hepatic enzyme activities in coho salmon (Oncorhynchus kisutch (Walbaum)). J Nutr 107, 1477-1483.

Lin H, Romsos DR, Tack PI \& Leveille G (1977b) Influence of dietary lipid on lipogenic enzyme activities in coho salmon (Oncorhynchus kisutch (Walbaum)). J Nutr 107, 846-854.

March BE, MacMillan C \& Ming FW (1985) Techniques for evaluation of dietary protein quality for the rainbow trout (Salmo Gairdneri). Aquaculture 47, 275-292.

Mashek DG \& Grummer RR (2003) Effects of long chain fatty acids on lipid and glucose metabolism in monolayer cultures of bovine hepatocytes. J Dairy Sci 86, 2390-2396.

Médale F, Brauge C \& Corraze G (1994) Effect of dietary non protein energy source on substrate oxidation and lipogenesis in rainbow trout. In Energy Metabolism of Farm Animals, pp. 133-136 [JF Aguilera, editor]. Madrid: Consejo Superior de las Investigaciones Cientificas, Servicio de Publicaciones.

Menoyo D, Lopez-Botea CJ, Bautista JM \& Obach A (2003) Growth, digestibility and fatty acid utilization in large Atlantic salmon (Salmo salar) fed varying levels of n-3 and saturated fatty acids. Aquaculture 225, 295-307.

Murat JC \& Serfaty A (1974) Simple enzymatic determination of polysacaride (glycogen) content in animal tissues. Clin Chem 20, $1576-1577$.

Ochoa S (1955) Malic enzyme. In Methods in Enzymology, vol. 11, pp. 739-753 [SP Olowick and NO Kaplan, editors]. New York: Academic Press.

Panserat S, Capilla E, Gutierrez J, Vachot C, Plagnes-Juan E, Aguirre $\mathrm{P}$, Brèque $\mathrm{J} \&$ Kaushik S (2001a) Dietary fructose does not specifically induce hepatic glucokinase expression in rainbow trout. $J$ Fish Biol 59, 455-458.

Panserat S, Médale F, Blin C, Brèque J, Vachot C, Plagnes-Juan E, Krishnamoorthy R \& Kaushik S (2000a) Hepatic glucokinase is induced by dietary carbohydrates in rainbow trout (Oncorhynchus mykiss), common carp (Cyprinus carpio) and gilthead seabream (Sparus aurata). J Am Physiol 278, R1164-R1170.

Panserat S, Médale F \& Breque J (2000b) Lack of significant longterm effect of dietary carbohydrates on glucose-6-phosphatase expression in liver of rainbow trout. J Nutr Biochem 11, 22-29.
Panserat S, Perrin A \& Kaushik S (2001b) High dietary lipids induce liver glucose-6z-phosphatase expression in rainbow trout (Oncorhynchus mykiss). J Nutr 132, 137-141.

Pieper A \& Pfeffer E (1980) Studies on the effect of increasing proportions of sucrose or gelatinized maize starch in diets for rainbow trout (Salmo gairdneri, R.) on the utilization of dietary energy and protein. Aquaculture 20, 333-342.

Raclot T \& Oudart H (1999) Selectivity of fatty acids on lipid metabolism and gene expression. Proc Nutr Soc 58, 633-646.

Rodehutscord M \& Pack M (1999) Estimates of essential amino acid requirements from dose-response studies with rainbow trout and broiler chicken: effect of mathematical model. Arch Anim Nutr 52, 223-244.

Rollin X, Médale F, Gutieres S, Blanc D \& Kaushik S (2003) Shortand long-term nutritional modulation of acetyl-CoA carboxylase activity in selected tissues of rainbow trout (Oncorhynchus mykiss). Br J Nutr 89, 803-810.

Rustan AC, Hustvedt BE \& Drevon ChA (1993) Dietary supplementation of very long chain n-3 fatty acids decreases whole body lipid utilization in the rat. J Lipid Res 34, 1299-1309.

Sanz M, Flores A \& López-Bote C (2000a) The metabolic use of energy from dietary fat in broilers is affected by fatty acid saturation. Br Poult Sci 41, 61-68.

Sanz M, López-Bote CJ, Menoyo D \& Bautista JM (2000b) Abdominal fat deposition and fatty acid synthesis are lower and $\beta$-oxidation is higher in broiler chickens fed diets containing unsaturated rather than saturated fat. J Nutr 130, 3034-3037.

SAS (1990) SAS/STAT User's Guide, 6.03 ed., Cary, NC: SAS Institute.

Shimeno S, Hosokawa H \& Shikata M (1996) Metabolic response of juvenile yellowtail to dietary carbohydrate to lipids ratios. Fish Sci 62, 945-949.

Suárez MD, Sanz A, Bazoco J \& García-Gallego M (2002) Metabolic effects of changes in the dietary protein: carbohydrate ratio in eel (Anguilla anguilla) and trout (Oncorhynchus mykiss). Aquac Int 10, $143-156$

Towle H, Kaytor EN \& Shih HM (1997) Regulation of the expression of lipogenic enzyme genes by carbohydrate. Annu Rev Nutr 17, $405-433$.

Tranulis MA, Dregni O, Christophersen B, Krogdahl A \& Borrebaek BA (1996) Glucokinase-like enzyme in the liver of Atlantic salmon (Salmo salar). Comp Biochem Physiol 114B, 35-39.

Walton MJ \& Cowey CB (1982) Aspects of intermediary metabolism in salmonid fish. Comp Biochem Physiol 73B, 59-79. 